\title{
Review: \\ The conservation of Tengger indigenous people's traditional knowledge of biological natural resource-based disease treatments
}

\author{
EMILDA KUSPRANINGRUM ${ }^{1, \bullet}$, THOHIR LUTH ${ }^{2}$, YULIATI $^{2}$, RACHMAD SAFA'AT ${ }^{2}$, \\ HARLINDA KUSPRADINI ${ }^{3}$ \\ ${ }^{1}$ Faculty of Law, Universitas Mulawarman. J1. Sambaliung Kampus Gunung Kelua, Samarinda75123 East Kalimantan, Indonesia. \\ Tel.: +62-541-7774145, `email: emildakuspraningrum@ fh.unmul.ac.id \\ ${ }^{2}$ Faculty of Law, Universitas Brawijaya. Jl. MT. Haryono No. 169, Malang 65145, East Java, Indonesia \\ ${ }^{3}$ Faculty of Forestry, Universitas Mulawarman. Jl. Penajam, Kampus Gunung Kelua, Samarinda 75123. East Kalimantan, Indonesia
}

Manuscript received: 5 March 2020. Revision accepted: 7 October 2020.

\begin{abstract}
Kuspraningrum E, Luth T, Yuliati, Safa'at R, Kuspradini H. 2020. Review: The conservation of Tengger indigenous people's traditional knowledge of biological natural resource-based disease treatments. Biodiversitas 21: 5040-5053. The indigenous people of Tengger, a community living around Bromo Mountain in East Java, frequently use ethnic knowledge to process biological natural resources into medicines used to cure diseases. These include Foeniculum vulgare Mill. tree, Tithonia diversifolia/insulin tree, Mikania cordata L. and Bidens pilosa tree, Cyphomandra betacea (Cav.) Sendtn., and Acorus calamus L. This intelligence is acquired consciously to solve health problems. In addition, the bond between the community and nature is highly philosophical, hence the presence of respect and maintaining the harmony of Knowledge obtained from nature ensures life continuity. Therefore, the belief is passed on through the generations, and traditional knowledge is attained following the gain of existence. This phenomenon is proven by numerous modern researches with scientific methods that admit the plant healing properties. In addition, traditional knowledge is a significant topic of interest in the United Nations' Convention on Biological Diversity, and was thus ratified by Law Number 5 of 1994. The object of this research is potential medicinal plants for healing and tengger indigenous people's conservation model is to provide a platform to protect the interest of biological resources, including their use in the field of medicines belonging to indigenous peoples. Therefore, the empirical interdisciplinary research involves the compilation of data from the collection of similar scientific journals, for use as evidence. This is important to ascertain the existence of traditional medicine based on natural resources, followed by integrations with other disciplines, including the laws to be developed concerning the best protection methods. Furthermore, this investigation is essential for identifying the philosophical values of Tengger people, the importance of knowledge conservation, and recognizing the laws and regulations-based efforts aimed at protecting information on plant-based medicine production from extinction and biopiracy. These considerations are important because the absence of government intervention, alongside the preservation of plant species and traditional knowledge on treatment predisposes the possibility of destruction.
\end{abstract}

Keywords: Convention on biological diversity, indigenous people, natural resources, traditional knowledge

\section{INTRODUCTION}

Nature basically provides everything needed by humans before technology took control of life, through environmental, especially biological resources. These materials are practically aged, and applied for survival. For example, people in the health sector initially used indigenous plants to cure illnesses.

Local inhabitants are often closer to the universe than other groups of people, and humans are also assumed to be inseparable from the universe, featuring the need for one another as a single entity. This dependency influences the individuals' mindset on the knowledge derived from nature, including the aspect of curing diseases. Furthermore, numerous approaches have been adopted to achieve remediation using plants, as seen in the Tengger indigenous people of East Java, featuring the practice of boiling, brewing, or steaming to attain the most appropriate and acceptable method for the body. Also, there are people known to generate treatment methods using supernatural means (Fanani and Dewi 2014; Kuspraningrum et al.2018; Meyers and Owoeye 2013). This millennium era is characterized by unavoidable modernity, and the individuals that initially entrusted personal health to the surrounding plants sought after chemical medicines sold in the market. The inception of an operating Community Health Center in the area further facilitated the abandonment of traditional methods (Satria 2013; Kuspraningrum et al. 2018; Fitri and Arso 2018), thus causing the extinction of valuable indigenous knowledge. These techniques are currently only practiced by those over the age of fifty, as young people prefer more practical ways. However, increasing government attention towards this wisdom is expected to improve the local economy.

Knowledge is "justified true belief" (Nonaka and Tekeuchi 1995), and everything assumed to be real is based on truth. Hence, awareness with an aim to identify objects at hand is considered as a capability of solving life's problems, through certain methods, as part of knowledge. This concept is based on the "tripartite account of knowledge," including 
the truth condition and this suggests that an understanding of a proposition is indicative of truth, otherwise, the person has no knowledge of what is claimed. These considerations distinguish opinion from knowledge. The condition requires that knowing a proposition facilitates believes and it is also important to develop practical ways to justify the possible authenticity, (Pritchard and Neta 2009). Moreover, it is part of knowledge to solve life problems and have certain methods (Bolisani and Bratianu, 2018).

Traditional knowledge is interpreted as an amalgamation of the amount of information continuously being developed, obtained, used, performed, and transmitted by communities through generations, supported by the environment, lifestyle, behavior, society, and culture (Daulay 2011; Wiradirja and Munzil 2018;). This was classified into agricultural, scientific, ecological, medicine (including related medicine and remedies), as well as biodiversity knowledge (WIPO). In addition, the world is familiar with various arts, including batik, dance, paintings, sculptures, recipes, traditional home architecture, and concoctions of Indonesian medicinal plants, and this is consistent with the WHO's report on Indonesia, showing the presence of around 20,000 medicinal plant species (Kusmana and Hikmat 2015; Nahdi et al 2019; Rohman et al 2019), needed to provide adequate welfare. However, the repeated practice of this knowledge allegedly passed down from previous generations, devises the term traditional knowledge (Kusumadara 2011; Janke 2019).

The United Nations' Convention on Biological Diversity, also referred to as CBD, is high-level and is often held in Rio De Janeiro, Brazil, with interest in indigenous traditional knowledge. In addition, Indonesia is one of the countries known to ratify this convention Law Number 5 of 1994, and this was considered a very appropriate step due to the abundant wisdom and utility of natural resources, especially for medicine. Therefore indigenous people are assumed to possess the relevant intelligence and creative abilities needed for production. The extinction of knowledge is an unfortunate outcome, imminent through replacement with chemical treatment products (Syah 2013; Fitrianatsany 2017; Lumintang 2015). A research review on the potential and efficacy of living natural resources, including plants traditionally processed by the Tengger indigenes, reinforces the importance of preserving the expertise. This paper, therefore, focuses on the life of the community, being one of the local peoples in Indonesia to use traditional natural resource-based medical knowledge to date.

\section{IN SITU CONSERVATION OF THE TENGGER COMMUNITY}

In situ conservation of medicinal plants is carried out by the Tengger indigenous people with their simple traditional knowledge of allowing the medicinal plants to grow around their natural habitat. They also achieve this by deliberately planting these plants in their yard, garden, and forest, without changing their conditions favorable for their growth (Kidane et al. 2014; Sing et al. 2014). According to AcostaVargas et al. (2020) irrespective of the treatment process used to regenerate plants, indigenous people tend to form small groups such as a neighborhood pillar with a program called a dispensary, which encourages each of them to grow medicinal plants on each page of their house (Amsalu et al. 2018; Khan, et al. 2011; Rojas et al. 2010). This process is effective because it enables the availability of medicinal plants when needed. For instance, when the indigenous people of Tengger feel unwell, they cook fennel plants, which warms their stomach and makes them feel well.

\section{UTILIZATION OF TRADITIONAL MEDICINAL PLANTS}

Tengger indigenous people are known to use medicinal plants still to cure some local and mild ailments. They tend to utilize traditional healers known as a shaman to receive a cure for various health diseases (Fenethun et al. 2017). Other advantage of community life behavior in Tengger tribe is that shaman do not hide their knowledge rather, the community uses it for their benefit (Ismail et al. 2019; Kuspraningrum et al. 2020b; Mahwasane et al. 2013). Traditional medicinal plants' knowledge is possessed by the Tengger indigenous people, which provides them with three components that are sustainably managed and protected. Firstly, adequate management of medicinal plants and their traditional knowledge increases business opportunities in the field of medicine, which are expected to increase income (Andriamparany et al. 2014; Mathibela et al. 2015). Secondly, few businesses seek potential and traditional knowledge to use medicinal plants (Akankwasah et.al 2012; Astutik et al. 2019). This is because the local and international business world is currently interested in traditional medicines based on plants and associated knowledge. Several countries use traditional, thereby leading to an increase in the production of medicinal plants. For instance, China, Japan, Chile, Colombia, France, Canada, Britain, and the United States use 90\%, 60-70\%, $70 \%, 40 \%, 49 \%, 70 \%, 40 \%$, and $42 \%$ of medical plants (Khan et al. 2011; WHO, 2013). This data shows that traditional medicine is still very popular in the world market. Thirdly, it obligates the government to encourage economic growth and stability, which in principle increases the community's income and economy. The societies as the main actors of the government are obliged to direct, guide, and protect those that are less aware of the conservation of medicinal plants. This is in a bid to prevent them from destroying medicinal plants and to ensure that irresponsible parties use it to seek profit through its production and trade (Deakin and Reid 2014; López et al. 2016). The inability of the Tengger tribe to properly utilize traditional medicine id detrimental to the community due to the numerous advantages associated with the use of medicinal plants (Mbuni et al. 2020; Verma and Singh 2008).

\section{THE TRADITIONAL KNOWLEDGE OF THE INDIGENOUS PEOPLE OF TENGGER}

Tengger is an Indonesian community in Bromo, East Java (Fig. 1), living in several regions, namely the villages of Ngadas, Jetak, Wonotoro, Ngadirejo, and Ngadisari 
(Sukapura and Probolinggo Districts), Ledokombo, Pandansari, and Wonokerso (Sumber and Probolinggo Districts), Tosari, Wonokitri, and Sedaeng (Probolinggo district), Ledokombo, Pandansari, and Wonokerso (Sumber and Probolinggo Districts), Tosari, Wonokitri, Sedaeng, Ngadiwono, Podokoyo (Kecamatan Kecamatan) Tosari, Keduwung (Puspo District, and Pasuruan Regency), Ngadas (Poncokusumo District, Malang Regency), and Argosari and Ranu Pani (Senduro District, Lumajang Regency) (Aziz et al 2011). In accordance with other traditional law communities (Table 1), the indigenes of Tengger live in groups, and gynecologically possess traditional rights with their various activities performed based on ancestral knowledge (Jaiswal 2019; Pager 2016; Tang 2016). In addition, Ter Haar helped in the understanding of customary law community, with the stipulation: "Indonesian ethnic groups are associated with layers consisting of hordes, people and natural materials that behave in specific ways (Ter harr 1979), therefore, it is referred as rechtsgemeenchap (legal community)" (Bedner and Arizona 2019; Larsen and Gilbert 2020; Moffatt 2012; UNESCO, 2011).

The proximity to the universe is of high philosophical value to indigenous people, and every element of life is permeated and assumed to be driven by an invisible entity. This supports humans, including terrestrial plants and animals, hence maintaining and preserving the gift of nature is perceived as an obligation. Furthermore, indigenous people consider land as the "mother" and provider of life, resulting from the ability to grow plants, which serve as a source for survival (Tang 2016; Kuspraningrum 2018) highlighted the unity between indigenous people and nature.

Biological resources, including plants, are used for treatment (Rohman et al 2019; Zulkarnain et al. 2019) by the Tengger community in the villages of Ngadas and Tosari. This is in agreement with Indriyani et al. concerning Ethnobotany of Medicinal Plants in the National Park of Bromo, Tengger, Semeru. (Indriyani et al. 2012; Kuspraningrum 2018) reported the statement of the community head, stipulating the use of indigenous plants, e.g., fennel, sempretan, insulin leaf, Dutch eggplant on the basis of empirical experience. Furthermore, fennel leaf, Foeniculum vulgare Mill, is used during cold weather, and also to treat stomach pain, by kneading the leaves and applying to the stomach. The younger leaves are possibly cooked for consumption due to the ability to provide a warm sensation. Also, the insulin tree is easy to find, and the leaves are applied to increase stamina. However, because they are widely used, the supply is large, and the knowledge in packaging is limited, dried insulin leaves are sold outside the area.

The indigenous people simply practice the ancestral teachings, and the government has not paid adequate attention to protect and encourage the utilization of biological resources, necessary to ensure the optimal production of traditional medicines for widespread use (Meyers and Owoeye 2013; Priambodo 2018; Kuspraningrum 2018)

To date, there have been numerous studies on plants in Indonesia, including drugs commonly used by the Tengger community, as shown in Table 1.
These previous studies showed five species with the highest use value in Ngadisari village. These include Foeniculum vulgare Mill, Aloe vera (L) Burm. F., Acorus calamus L, Apium graveolens L, and Allium fistulosum L (Kurniawan and Jadid 2015), while (Azrianingsih and Kusumahati 2019) reported Acorus calamus Linn, Brugmansia suaveolens L., and Foeniculum vulgare Mill. as the most used medicinal plant in Wonokitri village. In addition, other researchers have highlighted the habitual use of Pimpinella pruatjan Molkenb. (forest ginger), Abrus laevigatus Lour. (Krangean), Foeniculum vulgare Mill., and Astronia macrophylla Bl. by Tengger people outside the four villages (Wonokitri, Ranupani, Ngadas, and Ngadisari).

\section{RESEARCH ON MEDICINAL PLANTS}

The twenty-two species of Tengger's medicinal plants mentioned in Table 1 do not only grow in Tengger. Several studies and scientific validation about the twenty-two species of medicinal plants that grow in other areas have been published (Table 2).

Two out of twelve plant species (Astronia macrophylla L. and Calvatia sp.) mentioned in Table 2. have limited information on the scientific validation and traditional knowledge from another area. F. vulgare, A. calamus $\mathrm{L}$, and garlic (A. sativum L) are popular species with frequent application in Indonesia, and also worldwide. F. vulgare is an aromatic medicinal plant used to treat respiratory and gastrointestinal disorders, and the seeds have frequently been adopted as food flavorings and as component of herbal mixtures. Modern research proves the presence of antimicrobial, antioxidant, anti-inflammatory, anti-anxiety, anti-lipid, anti-diabetic, and anti-cancer properties (Rather et al. 2012. Kooti et al. 2015; Kuspradini et al. 2019; Kuspradini et al. 2020). Meanwhile, A. calamus has long been applied in traditional medicine, and also possesses anticarcinogenic and anti-angiogenic features (Imam et al. 2013; Haghighi et al. 2017). Garlic (A. sativum) is used as a medicinal agent for thousands of years, due to the antimicrobial, antioxidant, anti-inflammatory, and anticancer effects (Harris et al. 2001; Thomson and Ali 2003; Metwally et al. 2018; Rahman et al. 2012).

Searches from the patent website at the World Intellectual Property Organization (WIPO), the ASEAN Intellectual Property Portal (ASEAN IP), and the Intellectual Property of Indonesia Database, show that several plants have been registered and patented (Figure 2).

The data showed A. sativum $\mathrm{L}$. as the plant most frequently studied, and developed into various products. In the ASEAN and global context, P. pruatjan, A. laevigatus, Calvatia sp., A. macrophylla, A. reinwardtii, B. laevis, and E. horsfieldii have not been technologically patented. These related studies are occasionally developed based on prior public knowledge, although the documented origin is often forgotten. This makes it important to conserve the known and unknown indigenous medicinal plants, to preserve traditional knowledge from going extinct. 

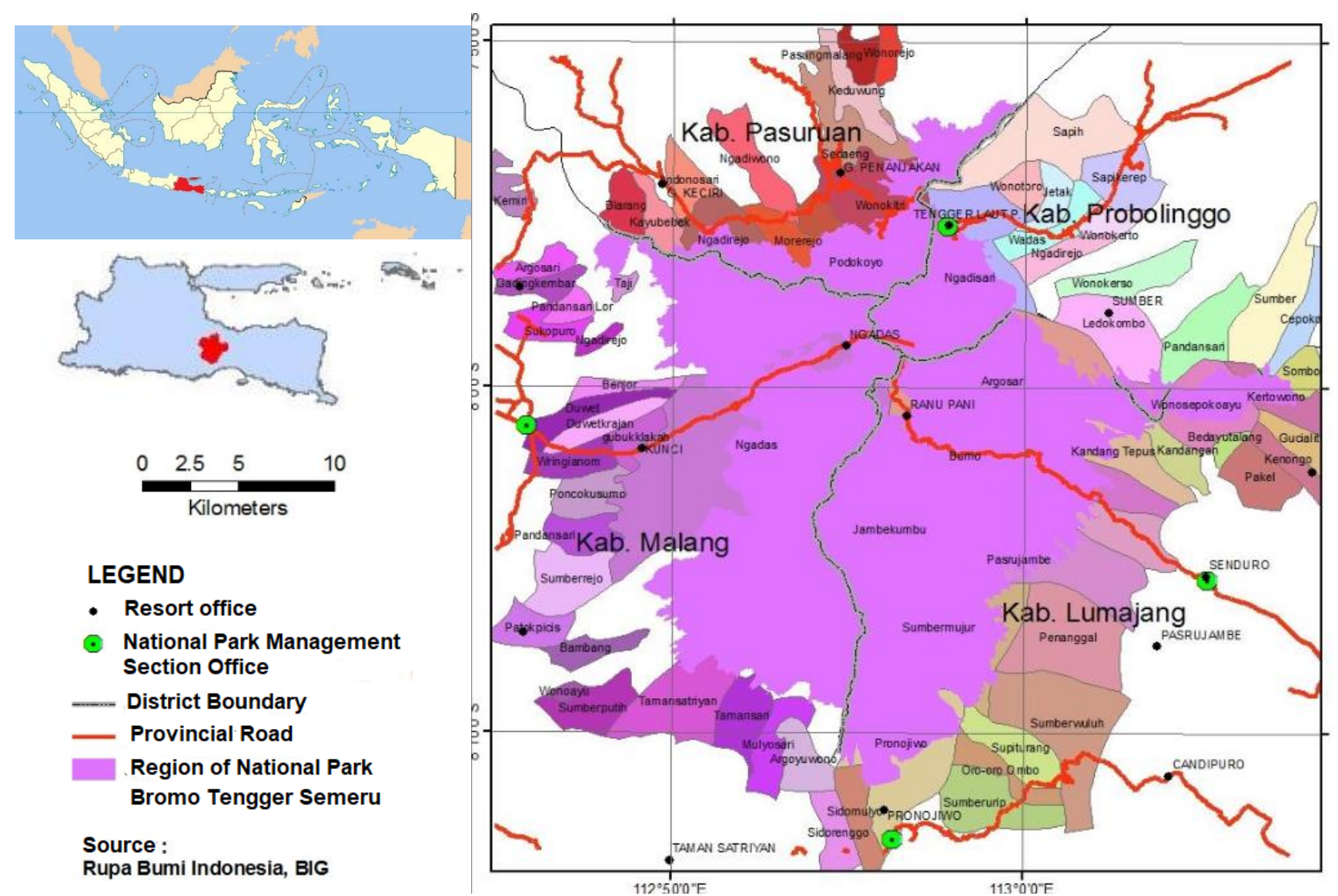

Figure 1. The Map of Bromo Tengger, East Java, Indonesia (Source: Rupa Bumi Indonesia)

\section{INTELLECTUAL PROPERTY PROTECTION FOR THE INDIGENOUS PEOPLE OF TENGGER}

The principle guarding the respect for fellow humans, providing balance, and the fulfillment of others' rights are contained in the Holy book of Muslims. In Surah Asy Syuaraa (183) the following "do not harm humanity in their rights and detest from running rampantly on the earth by damaging this surah, exemplifying humans as officers entrusted by God to maintain balance and justice" (AlQur'an AlKarim 2015). This is because humans tend to reason and realize a life order consisting of goodness and justice, all levels of society felt that. This divine principle is assumed to be parallel with the philosophical thinking of Aristotle, and Thomas Aquinas, which was used to realize the term "Prima Principia." This encompasses the teachings and rules for carrying out good deeds and avoiding bad things (Dalton et al. 2013; Ginsberg 1963; Luth et al. 2017; Murphy 2019; Obioha 2011; Wibisono et al. 2013). This is similar to the theory presented by Jhon Rawls, in the book "A Theory of Justice," which explained the link between natural and positive law. It is important to attain a balance while placing the cultural interests of the Tengger community and having regulations, is important to achieve. The state apparatus's duty and responsibility are reflected as a blend of justice and morality values (Filippini and Cavana, 2016; Graham et al. 2011; Heryanti 2017; Nurjaya and Safa'at 2016). The spirit to protect traditional knowledge is congruent with the CBD principles, as stipulated in article $8 \mathrm{~J}$, where the convention provides an opportunity to member states to form guideline support, through the respective national regulations. This approach is needed to guarantee treatment with quality traditional knowledge. It is assumed to be maintained and preserved for hundreds of years, as one of the cultural reserves, without the need for the replacement with factory processed chemical drugs. 


\section{WIPO}

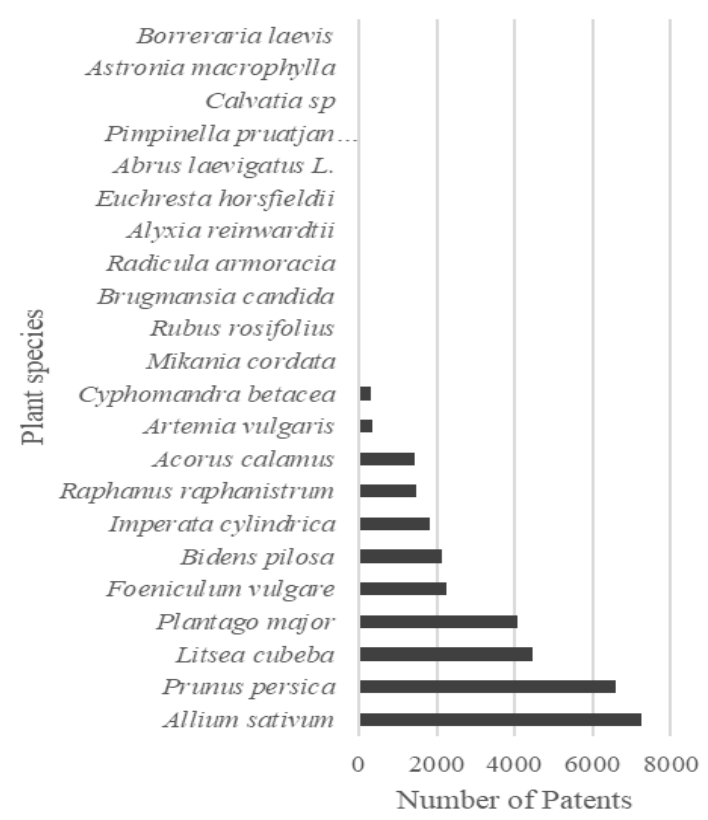

ASEAN IP

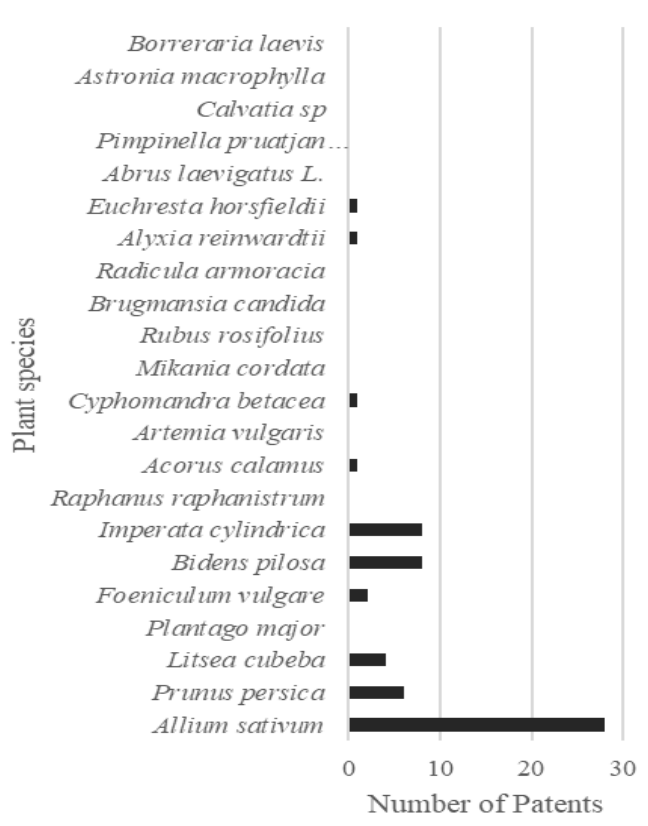

Figure 2. Plant Patents Database (until 2019) (Searching method: Based on plants used by Tengger Community)

Table 1. Medicinal plants used by Tengger community, East Java, Indonesia

\begin{tabular}{|c|c|c|c|c|}
\hline Scientific name & Local name & Usage of plant & Part of plant & Reference \\
\hline Allium sativum $\mathrm{L}$. & $\begin{array}{l}\text { Bawang putih } \\
\text { (garlic) }\end{array}$ & $\begin{array}{l}\text { For reducing fever, common cold, } \\
\text { and flatulence }\end{array}$ & - & $\begin{array}{l}\text { Batoro et al. (2011) } \\
\text { Indriyani et al. (2012) }\end{array}$ \\
\hline Brugmansia $x$ candida Pers. & $\begin{array}{l}\text { Air kuncup } \\
\text { kecubung gunung }\end{array}$ & For treating sore eye & - & Batoro et al. (2011) \\
\hline Prunus persica (L.) Batsch & Jambu wer & For treating diarrhea and gonorrhea & - & $\begin{array}{l}\text { Batoro et al. (2011); } \\
\text { Listiyana et al. (2017); } \\
\text { Aziz et al. (2019) }\end{array}$ \\
\hline Imperata cylindrica (L.) P. Beauv & Alang-alang & For remediating wounds & - & Batoro et al. (2011) \\
\hline Plantago major L. & Suripandak & For handling sprain and muscle ache & - & Batoro et al. (2011) \\
\hline Carica pubescens Lenne \& K.Koch & Pepaya (papaya) & $\begin{array}{l}\text { For reducing constipation and } \\
\text { treating sprues }\end{array}$ & & Batoro et al. (2011) \\
\hline Pimpinella pruatjan Molk. & Purwoceng & For uplifting stamina & All plant parts & Batoro et al. (2011) \\
\hline $\begin{array}{l}\text { Abrus laevigatus } \mathrm{L} . \\
\text { Litsea cubeba } \text { Pers. }\end{array}$ & Krangean & For treating high blood pressure & $\begin{array}{l}\text { Leaf, bark } \\
-\end{array}$ & $\begin{array}{l}\text { Indriyani et al. (2012) } \\
\text { Listiyana (2017) }\end{array}$ \\
\hline \multirow[t]{2}{*}{ Foeniculum vulgare Mill. } & Adas (Fennel) & $\begin{array}{l}\text { For reducing cough and asphyxiation } \\
\text { For treating cough, itchy, bloating, } \\
\text { smallpox pus, toothache }\end{array}$ & $\begin{array}{l}\text { Leaf, seed, root } \\
\text { - }\end{array}$ & $\begin{array}{l}\text { Indriyani et al. (2012) } \\
\text { Aziz et al. (2019) }\end{array}$ \\
\hline & & For reducing stomachache & Leaf & Kuspraningrum (2018) \\
\hline Astronia macrophylla Blume & Kayu ampet & For treating diarrhea & Young leaf, bark & Indriyani et al. (2012) \\
\hline Alyxia reinwardtii Blume & Pulosari & For reducing cough, fever, headache & $\begin{array}{l}\text { Leaf, bark, root, } \\
\text { seed }\end{array}$ & Indriyani et al. (2012) \\
\hline Acorus calamus L. & Dringu & For treating fever and common cold & Leaf, all plant parts & Indriyani et al. (2012) \\
\hline $\begin{array}{l}\text { Mikania cordata (Burm.f.) .L.Rob. } \\
\text { Bidens pilosa L. }\end{array}$ & Sempretan & $\begin{array}{l}\text { For remediating cough, muscle ache, } \\
\text { common cold }\end{array}$ & Rhizome, root & Indriyani et al. (2012) \\
\hline Calvatia sp. & Jamur impes & For reducing swells & & Indriyani \\
\hline Euchresta horsfieldii (Lesch.) Benn & Pronojiwo & For treating muscle ache, rheumatism & Fruit, seed & Indriyani et al. (2012) \\
\hline Borreria laevis (Lam.) Griseb. & Tepung otot & For treating muscle ache and sprain & All plant parts & Listiyana et al. (2017) \\
\hline Radicula armoracia B.L. Rob. & Asem Tengger & For remediating cough & - & Aziz et al. (2019) \\
\hline Artemisia vulgaris $\mathrm{L}$. & Ganjan & For treating nosebleed & - & Aziz et al. (2019) \\
\hline Rubus rosaefolius $\mathrm{Sm}$ & Grunggung & For remediating diarrhea & - & Aziz et al. (2019) \\
\hline Raphanus raphanistrum $\mathrm{L}$. & Lobak Tengger & $\begin{array}{l}\text { For treating gonorrhea, diarrhea, typhus } \\
\text { For increasing sexual desire }\end{array}$ & - & Aziz et al. (2019) \\
\hline Cyphomandra betacea (Cav.) Sendtn & Terong belanda & For increasing sexual desire & Fruit & Aziz et al. (2019) \\
\hline
\end{tabular}


Table 2. The scientific validation and worldwide traditional usage of medicinal plants

\begin{tabular}{|c|c|c|c|}
\hline Scientific name & Usage & Part & Reference \\
\hline \multirow[t]{3}{*}{ Allium sativum $\mathrm{L}}$. & $\begin{array}{l}\text { Antimicrobial activity against Klebsiella pneumoniae, Escherichia coli, Streptococcus pyogenes, } \\
\text { Pseudomonas aeruginosa, Enterobacter aerogenes, Staphylococcus aureus, Proteus vulgaris, Salmonella } \\
\text { typhi, Bacillus typhi, and Aeromonas hydrophila }\end{array}$ & Bulb & $\begin{array}{l}\text { Lekhsmi et al. (2015); } \\
\text { Khashan (2014) }\end{array}$ \\
\hline & Antioxidant activity using DPPH radical & Plant & Lenkova et al. (2016) \\
\hline & $\begin{array}{l}\text { Antioxidant, anti-inflammatory, antibacterial, antifungal, immunomodulatory, cardiovascular } \\
\text { protective, anticancer, hepatoprotective, digestive system protective, anti-diabetic, anti-obesity, } \\
\text { neuroprotective, and renal protective properties }\end{array}$ & - & Shang et al. (2019) \\
\hline Brugmansia x candida & An antispasmodic and a nodyne & - & Kaewklom et al. (2018) \\
\hline Pers. & Anticholinergic activity and for cigarette assortment, have relaxed effect & Leaves & Ibrahim et al. (2017) \\
\hline \multirow[t]{4}{*}{$\begin{array}{l}\text { Prunus persica }(\mathrm{L} .) \\
\text { Batsch }\end{array}$} & $\begin{array}{l}\text { Antibacterial activity against Escherichia coli, Klebsiella pneumoniae, Enterococcus faecalis, Staphylococcus } \\
\text { aureus, Bacillus }\end{array}$ & Bark & $\begin{array}{l}\text { Aziz and Rahman } \\
\text { (2013) }\end{array}$ \\
\hline & $\begin{array}{l}\text { subtilis, Salmonella typhi and Shigella flexenari, antifungal activity against Candida albicans, Aspergillus } \\
\text { flavus, Microsporum canis, Fusarium solani and Candida glabrata, phytotoxic activity against Lemna minor, } \\
\text { insecticidal activity against } \\
\text { Tribolium castaneum, Rhyzopertha dominica and } \\
\text { Callosbruchus analis. }\end{array}$ & & \\
\hline & $\begin{array}{l}\text { Antioxidant activity against DDPH, oxygen (ORAC), ABTS, PFRAP radicals, chelating activity for ferrous } \\
\text { ions } \mathrm{Fe}^{2+} \text {, fibril aggregation (Amyloid- } \beta \text { and } \alpha \text {-synuclein) inhibitory activity, Protective effects against } \mathrm{Ab} \text { - } \\
\text { induced cytotoxicity on PC12 cells }\end{array}$ & Fruit & Mokrani et al. (2015) \\
\hline & $\begin{array}{l}\text { Antioxidant activity by oxygen radical absorbance capacity (ORAC), anti-lipase activity, anti-dementia } \\
\text { activity }\end{array}$ & $\begin{array}{l}\text { Mature fruit, green fruit peel, } \\
\text { green fruit flesh, branch, bud, } \\
\text { flower }\end{array}$ & Nakagawa et al. (2018) \\
\hline Imperata cylindrica & Anti-hypersensitive activity & Root & Ruslin et al. (2013) \\
\hline \multirow[t]{2}{*}{ (L.) P. Beauv } & Anticancer & Leaves & Keshava et al. (2020) \\
\hline & Antifertility agent & Root & Widyastuti et al. (2018) \\
\hline \multirow[t]{4}{*}{ Plantago major L. } & Immune modulating property, anticarcinogenic, antidiabetic, anti-inflammatory, analgesic activity & - & Vandana et al. (2017) \\
\hline & $\begin{array}{l}\text { Wound healing, antipyretic, antitussive, anti-infective, anti-hemorrhagic, diuretic, laxative, astringent and } \\
\text { hemostatic }\end{array}$ & - & Najafian et al. (2018) \\
\hline & $\begin{array}{l}\text { Antiulcerative, antidiarrhoeal, antinociceptive, antibacterial (Bacillus subtilis, Staphylococcus aureus, } \\
\text { Candida albicans, Candida tropicalis, and Escherichia coli), antiviral agent (herpes virus and adenoviruses), } \\
\text { treatment for fatigue and cancer, antioxidant and a free radical scavenger (DPPH-radical), treatment for } \\
\text { common cold, conjunctivitis and viral hepatitis }\end{array}$ & Leaves, seed, flower, and root & Adom et al. (2017) \\
\hline & Antiinflammatory activity on oral epithelial cells & Leaves & Zubair et al. (2019) \\
\hline $\begin{array}{l}\text { Carica pubescens } \\
\text { Lenne \& K.Koch }\end{array}$ & Antioxidant activity against oxygen radical absorbance capacity (OPRAC), DPPH radical & Fruit, stem and leaves & $\begin{array}{l}\text { Pavan et al. (2014); } \\
\text { Rahayu et al. (2019) }\end{array}$ \\
\hline
\end{tabular}


Pimpinella pruatjan Molk.

Abrus laevigatus L.

Litsea cubeba Pers.

Treatment for gonorrhea, jaundice, and hemoglobinuria bile

Promotion of the growth of human hair

Anti-suppurative properties, in leucoderma, itching, and other skin diseases

Healing of painful swellings

Graying of hair

Effect on milk-induced leucocytosis and eosinophilia in the management of asthma, produced dose-dependent Leaves bronchodilator activity

Antiallergic

Antimicrobial activity against Bacillus subtilis, Staphylococcus aureus, and Saccharomyces cerevisiae

Insecticidal activities against cigarette beetles and

booklice (for stored products)

Foeniculum vulgare

Mil.

Root aerial parts
Anti-termite activity and repellent against Heterotermes indicola

Anti-inflammatory, antispasmodic, antiseptic, carminative, diuretic, and analgesic effect and is effective in gastrointestinal disorder treatment

Antifungal activity against various fungal species such as Candida albicans, species of Aspergillus, and dermatophytes, fungi in food waste such as Aspergillus niger and Fusarium oxysporum Antioxidant activity on DPPH, hydrogen peroxide radical, reducing ability (FRAP)

Antimycobacterial activity against Mycobacterium tuberculosi

Anti-anxiety activity, hold promising effects in the treatment of anxiety and stress, anti-stress proceeding, increase in memory and antioxidant effects may reduce stress and stress-related disorders

Gastro-protective activity

estrogenic effects for treatment of infertile women

Anti-diabetic activity

Hepatoprotective activity

Enhancement of memory and intelligence

Purwestri et al. (2016)

Root, Essential oil from Nurcahyanti et al. (2016)

Root

Seed oil

Leaves

The juice is employed as Manisha

cure for hoarseness;

mixed with oil

paste of leaves and seeds Garaniya and Bapodra (2014) is applied

Essential oil from bark, Hammid and Ahmad (2015)

leaf, root, fruit, and stem

Essential oil of fruit

Seed

Essential oil, seed

Stem and leaves

$-$

Essential oil
Kanedi et al. (2017)

Chinnappan and Rathinam

(2011)

Garaniya and Bapodra (2014)

Garaniya and Bapodra (2014)

Acharya and Roy (2013)

Manisha et al. (2013); Arora et

al. (2011)

Taur and Patil (2011); Mensah et al. (2011); Shourie and Kalra (2013)

Yang et al. (2014)

Aihetasham et al. (2017)

Delaram et al. (2011)

Rahimi and Ardekani (2013); Badgujar et al. (2014)

Chatterjee et al. (2012); Shahat et al. (2011)

Esquivel-Ferriño et al. (2012)

Pourabbas et al. (2011); Mesfin et al. (2014); Koppula and

Kumar (2013)

Al-Mofleh et al. (2013)

Mirabolghasemi and Alizadeh

(2014)

El-Soud et al. (2011)

Qiang (2011)

Badgujar et al. (2014) 
Alyxia reinwardtii

Blume

Acorus calamus L.

\section{Antioxidant activity using DPPH, superoxide, and lipid peroxidation}

cancer chemoprevention

Allelopathic activity, cytotoxic activity and antifungal activity against Aspergillus niger

Wound healing, mitogenic, insecticidal, anthelmintic, antiepileptic, antispasmodic and inhibitor of acetylcholinesterase

Mikania cordata (Burm.f.) B.L.Rob

Bidens pilosa L.

Calvatia sp.

Euchresta horsfieldii

(Lesch.) Benn.

Antibacterial activity against Staphylococcus aureus, Bacillus subtilis, Bacillus cereus, Bacillus megaterium

Salmonella typhi, Shigella dysenteriae, Escherichia coli, Shigella flexneri, and cytotoxic activity

Antinociceptive activity, antibacterial activity against Staphylococcus epidermidis, Enterococci, Shigella sonnei, Streptococcus pyogenes, Pseudomonas aeruginosa

Antioxidant activity using DPPH radical and TEAC (Trolox Equivalent Antioxidant Capacity)

aeruginosa $S$, aureus, $B$. subtilis, $M$. luteus, and larvacidal activity against $C$. quinquefasciatus

Sources of food and/or traditional medicine.

Borreria laevis (Lam.) Treatment of kidney and prevent of menstruation problems

Griseb.

Radicula armoracia

B.L. Rob

Artemisia vulgaris

Antibacterial activity against Staphylococcus aureus, Bacillus subtilis, Pseudomonas aeruginosa, Salmonella typhi, Candida albicans

Antioxidant activity against DPPH radicals and antibacterial activity against Staphylococcus aureus, Bacillu subtilis, Klebsiella pneumonia, Enterococcus sp.

Antibacterial activity against Escherichia coli and Staphylococcus aureus, antifungal activity against Candida albicans, and antihelmintic activity against Haemonchus contortus

Rubus rosaefolius $\mathrm{Sm}$ Antioxidant activity using DPPH free radical and FRAP reduction capability

Raphanus

raphanistrum $\mathrm{L}$

\section{Stem}

Essential oil of

leaves and rhizomes

Leaves

activity on DPPH, anti-cancer and antimive activity, antiurolithiatic activity, anti-tyrosinase and antioxidant

Salmonella typhi, Bacillus subtilis, and many foods born pathogenic and food spoilage bacteria such as

Listeria, Micrococcus, Enterococcus, Lactobacillus, and Pedicoccusspps, gastroprotective activity

Antioxidant activity using DPPH and minerals of natural origin, antiproliferative properties

Antidiabetic effects

Cyphomandra betacea Antiproliferative activity, potential as an effective agent in cancer therapy

(Cav.) Sendtn
Leaves

Flower

Fungal

Batang, akar, bij

Leaf

Decoction of the

leaves

Leaves

Leaves, essent

from leaves

leaves

Leaves

Ali et al. (2011)

Nayeem et al. (2011)

Lee et al. (2013)

Singh et al. (2017)

Coetzeel and Van Wyk (2009)

Prihatin et al. (2018)

Gunawan et al. (2016)

Conserva and Junior (2012)

Aziz (2019)

Pandey et al. (2017)

Malik et al. (2019)

Desmiaty et al. (2018)

Mohammed and Hameed (2018)

Jdey et al. (2017)

Küçükboyaci et al. (2012); Marrelli et al. (2015)

Banihani (2017)

Mutalib et al. (2017); Mutalib et al. (2016)

Fruit

Fruit 
Indonesia is known as one of the megadiverse countries, characterized by a wealth of natural resources, with failure to translate the biodiversity into economic wealth. In addition, there is a huge potential to advance medical knowledge (Senanayake 2006; Costanza 2013; Mahendradhata et al. 2017), which is very interesting and also anxious about western countries. Therefore the protection is needed to avoid exploitation by western society, especially without permission, and subsequently patented and developed in these countries, including America (Mgbeoji 2007; Kobayashi 2009; Banarjee and Alavalapati 2010; Blackeney 2019).

Support and efforts are needed to realize uniformity in the protection of traditional knowledge related to indigenous medicine, at the world level. In addition, it is necessary to make efforts regarding the security and recognition of biological diversity-based traditional medicine knowledge belonging to indigenous peoples (Safa'at 2013; Qodriyatun 2016; Arizona and Bedner 2019), and provide certainty to modern researchers developing biodiversity potential. Also, attention and concern is needed in the aspect of biopiracy, resulting from the illegal invasion of resources (Blackeney 2004; Zainol et al. 2011; Danley 2012; Vega 2018; Ageh and Lall 2019;). This was described by the CBD Secretariat as a practice that "exploits" biodiversity for commercially valuable genetic and biochemical reserves (UNEP 2000; Battacharya 2014; Das 2020).

A famous biopiracy and patent case is the patent on Neem (Azadirachta indica) extract, from India, by the US company W.R. Grace \& Company, and the US Department of Agriculture, at the US Patent and Trademarks Office (USPTO), and European Patent Office (EPO), in 1994. The patent was concerned with the method of extracting azadirachtin from Mimba seeds, for use as an insecticide. In addition, traditional knowledge was only considered as an inspiration, and the findings were assumed to be novel, and distinct from the original products of nature. This was, therefore, opposed by an environmental NGO, on the grounds that traditional knowledge held by Indian people is a novelty that is not possessed by western societies and the fungicide effect of Mimba seeds has been exploited for a long time in Indian society for 2000 years (Shiva 2013; Sharma et al 2018; Kumar 2019). Another example is in Australia, where the preparation of dried powder of Terminalia ferdinandiana, a source of food and traditional medicine for indigenous Northern Australian (Gorman et al. 2006; Bosse 2016; Robinson and Raven 2017), was patented through the US patent office. This right issued for lack of novelty, and the lawsuit is strengthened by the statements on prior application as medicine by the Aboriginal Society in Australia, for over 40,000 years. Therefore, the objection was communicated to the US applicants, and then the Australian application was withdrawn (Robinson 2010). The cases of biopiracy show the role of traditional community knowledge in identifying genetic resources.

Intellectual property in this aspect is actually facilitated by the Convention of Biological Diversity. Furthermore, Article $8(\mathrm{~J})$ shows the need for holders to participate in the "equitable sharing of benefits resulting from the application of knowledge, innovations, and practices," while article 16 of the CBD stipulated that "holders must participate in" equitable sharing of benefits arising from the utility ". Moreover, article 27 of the TRIPs reported on the possibility to grant patents in all matters related to the field of technology, including biotechnology, identified through the traditional assistance of public knowledge. Therefore, preservation is achievable by combining two elements, including; (i) the application of specific indigenous wisdom requires permission from the local community, as well as an agreement (Persoon and Minter 2011; Palar and Rasiah 2019; Ahyar and Kristiyanto 2017). "The preparation of this arrangement requires the user to have access permission, and a follow up on information obtained, involves an agreement between both parties with the help of a government agency. This is a document to be included in the application for use permits, and is needed to exercise prudence because natural resources are a source of income, as well as the main capital (Saleng 2013, Rinaldi 2015; Kuspraningrum et al. 2020) to be preserved (ii) through research collaboration (Conley and Moote 2003; Ushie 2013; Thomas et al. 2016; Packer et al. 2019) between the indigenes and researchers. The approach is performed for the scientific method not to obstruct traditional identity and claim authenticity of genetic material used during the research, (Braye et al. 2006; Joshi and Chelliah 2013; Blackeney 2019). This is in accordance with Article 15 of the CBD, where the goals derived from contracts include "create conditions facilitating the access to genetic resources for environmentally-friendly purposes," achieved using mutually agreed terms and conditions, based on "information-based agreement". (iii) To open access and provide a place where the government supports an opportunity by facilitating traditional knowledge (Alshehri and Drew 2010; Aisyah 2013; Lazuardini et al. 2014; Abyot et al. 2014; Dilksawan et al. 2018; Reny et al. 2020.) for adequate performance and recognition of companion treatment besides the existing modern treatments. (iv) In addition, a new breakthrough is also needed to accommodate traditional medical knowledge derived from natural resources, to ensure the safe entry into the intellectual property rights protection system (Correa 2001; Subramanian and Shaver 2011; Safa'at 2011; Safa'at 2013; Kuspraningrum 2018; Moh-ud-din et al. 2019). This concern is important to strengthen the existence of indigenous peoples and the wisdom in the field of herbal medicine, while enhancing permit access and benefit-sharing, as expected, through conventions on biological diversity, and automatically preserving the indigenous information on herbal medicine.

In conclusion, the local people of Tengger, East Java, have identified the genetic resources with possible applications in medicine. Therefore, it is necessary to obtain regulations with the guarantee of justice for both the indigenes as the first indigenous people to discover genetic resources and researchers on a mission to explore intrinsic potentials, using modern laboratory methods. The results showed a need to attain an appropriate formula to protect and preserve the existence of traditional medical knowledge. This is also needed to accommodate the direction of the 
convention on biological cities, to ensure a fair distribution of benefits for the indigenes. Furthermore, the blueprint needs to be incorporated into the intellectual property rights protection system to enable all parties to realize suitable benefits in the future, including the general public, and especially the indigenes known to have not received justice following the long term exploitation of knowledge. Meanwhile, it is also possible for the intellectual property rights system to serve as a media for accommodating these aspirations by creating more friendly entitlements in communities, as commonly found in customary law systems. It is also essential to determine the potential for knowledge of traditional medicine based on medicinal plants, such as garlic, mountain amethyst water, Jambu wer, Alang-alang, Suripandak, Papaya (papaya, Purwoceng, Krangean, Fennel, Kayu ampet, Pulosari, Dringu, Sempretan, Mushroom impes, Pronojiwo, Muscle flour, Muscle flour, Asem Radak Tengger, and Dutch eggplant. Future research of this review has the ability to strengthen the formation of policies to protect traditional medicine knowledge based on biological natural resources.

\section{ACKNOWLEDGEMENTS}

The authors are grateful to the late Jazim Hamidi, and Dr. Moh. Fadli, Faculty of Law, University Brawijaya's, for the inspiration and motivation provided at the inception of this research, related to Traditional Knowledge, obtained through comparative studies, references, and experiences. This paper was also supported by the LPDP BUDI Scholarship from the Ministry of Research and Technology, Republic of Indonesia. Also, the authors appreciate Dr. M. Ali Syafaat, Faculty of Law, Universitas Brawijaya, Malang, Indonesia, and Dr. Mahendra Putra Kurnia, Faculty of Law, Mulawarman University, Samarinda, Indonesia for supporting the research stage.

\section{REFERENCES}

Abyot E, Zewdu B, Tafera B, Mohammedberhan AW, Mulugeta F. 2014 Capacity building of traditional practitioners as primary health care workers in Gondar Town Northwest Ethiopia. J Homeop Ayurv Med 3 (3): 151-155. DOI: 10.4172/2167-1206.1000151.

Acharya R, Roy S. 2013. A review on the therapeutic utilities and purificatory procedure of Gunja (Abrus precatorius Linn.) as described in Ayurveda. J AYUSH 2 (1): 1-9. DOI: 10.37591/joayush.v2i1.1866

Acosta-Vargas L, Rovere AE, Camacho-Sandova J. 2020. Effectiveness of two treatments to promote tree regeneration: implications for forest restoration in the Isla del Coco National Park, Costa Rica. Revista de $\begin{array}{lllll}\text { biologia tropical } 68 & \text { (S1): } & \text { S103-S114. DOI: }\end{array}$ 10.15517/rbt.v68iS1.41172

Adom MB, Muhammad T, Muhammad FM, Mohamad SA, Muhammad BAK, Mohd WAWS, Pinaki S, Deny S. 2017. Chemical constituents and medical benefits of Plantago major. Biomed Pharmacother 96: 348-360. DOI: 10.1016/j.biopha.2017.09.152.

Ageh PA, Lall N. 2019. Biopiracy of plant resources and sustainable traditional knowledge system in Africa. Glob J Comp Law 8: 162-181. DOI: 10.1163/2211906X-00802003.

Ahyar, Kristiyanto EN. 2017. Local wisdom and role of society in spatial planning in the region. 1st International Conference on Law, Governance and Islamic Society (ICOLGIS), Advance in Social Science, Education and Humanities Research 413: 15-25.
Aihetasham A, Muhammad SA, Maryam U, Khalid ZR, Muhammad ID. 2017. Bioactivity of extracts of Foeniculum vulgare and Ocimum basilicum against Heterotermes indicola (Wasmann). Pak J Zool 49 (6): 2193-2199. DOI: 10.17582/journal.pjz/2017.49

Aisyah S. 2013. Peningkatan pemerintah dan masyarakat sebagai upaya menjaga ekosistem dan konservasi lingkungan di Dieng plateau. Jurnal Organisasi dan Manajemen 9 (2): 135-144. [Indonesian]

Akankwasah B, Tabuti JR, Van Dame P, Muwanika VB. 2012. Potential for commercialization and value ChainImprovement of wild food and medicinal plants for Livelihood enhancement in Uganda. J.Biological Sciences 4 (2): 108-116.

Al-Mofleh I, Al-Sobaihani M, Alqasoumi S, Al-Said M, Al-Dosari M, AlYahya M, Rafatullah S. 2013. Fennel "Foeniculum vulgare" treatment protects the gastric mucosa of rats against chemically-induced histological lesions. Intl J Pharm 9 (3): 182-189. DOI: 10.3923/ijp.2013.182.189.

Al-Quran. Holly Book of Mosleem Surah Asy Syuaraa 183.

Ali Md. S, Md. Saiful I, Md. Masudur R, Md. Rabiul I, Mohammed AS, Md. Rafikul I. 2011. Antibacterial and cytotoxic activity of ethanol extract of Mikania Cordata (Burm.F.) B.L. Robinson leaves. J Basic Clin Pharm 2 (2): 103-107.

Alshehri M, Drew S. 2010. Implementation of e-government: Advantages and challenges. Proceedings of the IASK International Conference EActivity and Leading Technologies \& InterTIC, Griffith Research Online, Griffith University, Australia.

Amsalu N, bezie Y, Fentahun M, Alemayahu A, Amsalu G 2018. Use and Conservation of medicinal plants by Indigenous People of Gozamin Wereda, East Gojjam Zone of Amhara region, Ethiopia: An ethnobotanical approach. J. Evid based Coml Alter Med. 19. DOI: 10.1155/2018/2973513.

Andriamparany JN, Brinkmann K, Jeannoda V, Buerkert A, 2014. Effects of Socioeconomic household characteristics on traditional knowledge and usage of wild Yams and medicinal plants in Mahafaly region of south0weter Madagascar. J Ethnobiol Ethnomed. Vol 10:82 DOI: 10.1186/1746-4269-10-82.

Arizona Y, Bedner A. 2019. Adat in Indonesia land law: A promise for the future or a dead end?. Asia Pac Anthropol 20 (5): 416-434. DOI: 10.1080/14442213.2019.1670246.

Arora R, Gill NS, Kaur S, Jain AD. 2011. Phytopharmacological evaluation of ethanolic extraction of the seed of Abrus precatorius Linn. J Pharmacol Toxicol 6: 580-588. DOI: 10.3923/jpt.2011.580.588.

ASEAN IP Portal, Asean PatentScope. 2019. http: //ipsearch.aseanip.org/wopublish-search/public/patents?1

Astutik S, Pretzsch J, Kimengsi JN, 2019. Asian medicinal plant production and utilization Potentials: A review. J Sustainability 1 (9) DOI: 10.3390/su11195483.

Atiqah NAAK, Maisarah A, Asmah R. 2014. Comparison of antioxidant properties of tamarillo (Cyphomandra betacea), cherry tomato (Solanum lycopersicum var. cerasiform) and tomato (Lycopersicon esculentum). Intl Food Res J 21 (6): 2355-2362.

Aziz N, Artiningsih, Gayo AA, Hastuty H, Purwanto, Hajeraty, Muchlisi AF, Wahyono H, Adharinalty. 2011. Laporan Akhir Pemantauan dan Inventarisasi Perkembangan Hukum Adat Badan Pembinaan Hukum Nasional. Kementerian Hukum dan Hak Asasi Manusia RI, Badan Pembinaan Hukum Nasional, Jakarta. [Indonesian]

Aziz S, Habib UR. 2013. Biological activities of Prunus persica L. Batch. J Med Plants Res 7 (15): 947-951. DOI: 10.5897/JMPR12.232.

Aziz YS, Peranginangin JM, Sunarni T. 2019. Ethnomedicine studies and antimicrobial activity tests of plants used in the Tengger Tribal Community. 1st International Conference of Health, Science and Technology (ICOHETECH)..

Azrianingsih R, Kusumahati A. 2019. Perception and Appreciation of Tenggerese of Medicinal Plants in Wonokitri Village, Tosari Subdistrict, Pasuruan Regency. Conference Paper in AIP Conference Proceedings October 2018. DOI: 10.1063/1.5061852

Badgujar SB, Patel VV, Bandivdekar AH. 2014. Foeniculum vulgare Mill: A review of its botany, phytochemistry, pharmacology, contemporary application, and toxicology. BioMed Res Intl. DOI: $10.1155 / 2014 / 842674$.

Banarjee O, Alavalapati J. 2010. Illicit exploitation of natural resources the forest concession in Brazil. J Policy Model 32 (4): 488-504. DOI: 10.1016/j.jpolmod.2010.06.001.

Banihani SA. 2017. Radish (Raphanus sativus) and diabetes. Nutrients 9 (9): 1014. DOI: 10.3390/nu9091014. 
Batoro J, Setiadi D, Chikmawati T, Purwanto Y. 2011. Pengetahuan tentang tumbuhan masyarakat Tengger di Bromo Tengger Semeru Jawa Timur WACANA, Jurnal Sosial dan Humaniora 14 (1): 1-10. [Indonesian]

Blackeney M. 2004. Bioprospecting and biopiracy. In: Ong B (ed) Intellectual Property and Biological Resources. Marshal Cavendish, Singapore.

Blackeney M. 2019. Remedying the Misappropriation of Genetic Resources. Springer Nature Singapore Pte Ltd., Singapore.

Bolisani E, Bratianu C. 2018. The Elusive Definition of Knowledge. In Bolisani E, Bratianu C. 2018. Emergent knowledge strategies: strategic thinking in knowledge management. Springer International Publishing, Cham.

Bosse J. 2016. Biopiracy in Queensland, a broken record that's need repair. Trade Insight 12 (2): $35-38$

Braye S, Shoot P, Michael. 2006. The role of the law in welfare reform: Critical perspectives on the relationship between law and social work practice. Intl J Soc Welf 15 (1): 19-26. DOI: 10.1111/j.1468 2397.2006.00603.x.

Chatterjee S, Goswami N, Bhatnagar P. 2012. Estimation of phenolic components and in vitro antioxidant activity of fennel (Foeniculum vulgare) and ajwain (Trachyspermum ammi) seeds. Adv Biores 3 (2): 109-118.

Chinnappan A, Rathinam S. 2011. Studies on wound healing activity of red and block coloured seed, white coloured seed extracts of Abrus precatorius L. Intl J Pharma Bio Sci 2 (1): 302-312.

Coetzeel JC, Van Wyk AE. 2009. The genus Calvatia ('Gasteromycetes', Lycoperdaceae): A review of its ethnomycology and biotechnological potential. Afr J Biotechnol 8 (22): 6007-6015. DOI: 10.5897/AJB09.360.

Conley A, Moote MA. 2003. Evaluating collaborative natural resource management. Soc Nat Resour Manage 16: 371-386. DOI $10.1080 / 08941920390190032$.

Conserva LM, Junior JCF. 2012. Borreria and Spermacoce species (Rubiaceae): A review of their ethnomedicinal properties, chemical constituents, and biological activities. Pharmacogn Rev 6 (11): 46-55. DOI: $10.4103 / 0973-7847.95866$

Correa CM. 2001. Traditional Knowledge and Intelectual Property. Quaker United Nations Office Geneva, Switzerland.

Costanza R, Alperovitz G, Daly HE, Farley J, Franco C, Jackson T, Kubiszwesky I, Scor J, Victor P. 2013. Building A Sustainable and Desirable Economy-in Society-in Nature. ANU Press, Canberra.

Danley V. 2012. Biopiracy in the Brazilian amazon: Learning from international and comparative law successes and shortcomings to help promote biodiversity conservation in brazil. Florida A \& M University Law Review 7 (8): 291-327.

Das BK, Swamy AHMV, Basavaraj CK, Pramod CG. 2019. Experimental evidence for use of Acorus calamus (Asarone) for cancer chemoprevention. Heliyon. 5 (5): e01585. DOI: 10.1016/j.heliyon.2019.e01585.

Das K. 2020. The global quest for green gold: implications of bioprospecting and patenting for indigenous bioresources and knowledge. Society And Culture. South Asia J 6 (1): 74-97. DOI: $10.1177 \% 2 F 2393861719883068$.

Daulay Z. 2011. Pengetahuan Tradisional, Konsep, Dasar Hukum dan Praktik. PT Raja Grafindo Persada, Jakarta. [Indonesian]

Deakin M and Reid A. 2014. Sustainable urban development: use of environmental assessment methods, J. Sustainable Cities and Society. Vol. 10:39-48. DOI: 10.1016/j.scs.2013.04.002.

Delaram M, Kheiri S, Hodjati MR. 2011. Comparing the effects of Echinophora platyloba, fennel, and placebo on pre-menstrual syndrome. J Reprod Infertil 12 (3): 221-226.

Desmiaty Y, Berna E, Fadlina CS, Muhammad H, Rini P. 2018 Antioxidant activity of Rubus fraxinifolius Poir. and Rubus rosifolius J.Sm. leaves. J Young Pharm 10 (2s): s93-s96. DOI: 10.5530/jyp.2018.2s.18.

Diep T, Chris P, Michelle Y. 2020. Phenolic and anthocyanin compound and antioxidant activity of tamarillo (Solanum betaceum Cav.). Antioxidants 9 (2): 169. DOI: 10.3390/antiox9020169.

Dilksawan, Hadi SP, Samekto A, Sasongko DP. 2018. History of an environmental impact assesment in Indonesia. Jurnal Pengelolaan Lingkungan Hidup Berkelanjutan 2 (1): 55-68. DOI 10.36813/jplb.2.1.55-68. [Indonesian]

El-Soud N, El-Laithy N, El-Saeed G, Wahby M, Khalil M, Morsy F, Shaffie N. 2011. Antidiabetic activities of Foeniculum vulgare Mill. essential oil in streptozotocin-induced diabetic rats. Macedonian J Med Sci 4 (2): 139-146. DOI: 10.3889/MJMS.1857-5773.2011.0173.
Esquivel-Ferriño PC, Favela-Hernández JMJ, Garza-González E, Waksman N, Ríos MY, Camacho-Corona MdR. 2012. Antimycobacterial activity of constituents from Foeniculum vulgare var. Dulce grown in Mexico. Molecules 17 (7): 8471-8482. DOI: 10.3390/molecules 17078471.

Fanani S, Dewi TK. 2014. Health Belief Model, Model pada pasien pengobatan alternatif supranatural dengan bantuan dukun. Jurnal Psikologi Klinis dan Kesehatan Mental 3 (1): 54-59. [Indonesian]

Fenetahun Y, Eshetu G, Worku A, Abdella T. 2017. A survey on medicinal plants used by traditional healers in Harari regional State, East Ethiopia. J Med Plants Stud 5 (1): 85-90.

Filippini L, Cavana A. 2016. The Latin American Casebook: Court Constitution and Right (Chapter 7). Routledge, New York.

Fitri ROD, Arso DD. 2018. Eksplorasi pengetahuan obat tradisional dalam perspektif hukum kekayaan intelektual di Bengkulu. Jurnal Mimbar Hukum 30 (2): 304-315. [Indonesian]

Fitrianatsany. 2017. Urban desa proses transisi desa menjadi kota (studi kasus di desa Panggungharjo Sewon Bantul Yogyakarta). Jurnal Sosiologi Agama 11 (2): DOI: 10.14421/jsa.2017.112-03. [Indonesian]

Ganjewala D, Ashwani KS. 2011. An update on chemical composition and bioactivities of Acorus species. Asian J Plant Sci 10 (3): 182-189. DOI: 10.3923/ajps.2011.182.189.

Garaniya N, Bapodra A. 2014. Ethnobotanical and phytopharmacological potential of Abrus precatorius L.: A review. Asian Pac J Trop Biomed 4 (1): S27- S34. DOI: 10.12980/APJTB.4.2014C1069.

Ginsberg M. 1963. The Concept of Justice. Cambridge University Pers 38 (144): 99-116.

Gorman JT, Griffiths AD, Whitehead PJ. 2006. An analysis of the use of plant products for commerce in remote Aboriginal communities of Northern Australia. Econ Bot 60 (4): 362-373. DOI: 10.1663/00130001 (2006)60[362: AAOTUO]2.0.CO;2.

Graham J, Nosek BA, Haidt J, Iyer R, Koleva S, Dito PH. 2011. Mapping the moral domain. J Pers Soc Psychol 101 (2): 366-385. DOI: $10.1037 / \mathrm{a} 0021847$

Gunawan IWG, Suastika K, Putra AAB. 2016. Potential of Euchresta Horsfieldii Lesch Benn leaf extract prevents oxidative stress through decrease of malondialdehyde levels and profile histopathology pancreatic $\beta$-cells in diabetic rats. World J Pharm Pharm Sci 5 (1): $1340-1352$

Haghighi SR, Asadi MH, Akrami H, Baghizadeh A.2017. Anticarcinogenic and anti-angiogenic properties of the extracts of Acorus calamus on gastric cancer cells. Avicenna J Phytomed 7 (2): 145-156.

Hammid SA, Ahmad F. 2015. Chemotype of Litsea cubeba essential oil and its bioactivity. Nat Prod Commun 10 (7): 1301-1304

Harris JC, Cottrell S, Lloyd D. 2001. Antimicrobial properties of Allium sativum (garlic). Appl Microbiol Biotechnol 57 (3): 282-286. DOI: 10.1007/s002530100722.

Hassan SHA, Bakar MFA. 2013. Antioxidative and anticholinesterase activity of Cyphomandra betacea fruit. Scientific World J. DOI: $10.1155 / 2013 / 278071$

Heryanti. 2017. Kajian Filsafat tanggungjawab negara terhadap nilai-nilai kearifan lokal masyarakat hukum adat. Holrev 1 (1): 75-85. [Indonesian]

Ibrahim S, Dewi AN, Mai E. 2017. Isolation and characterisation of alkaloid from leaves of Brugmansia candida. J Chem Pharm Res 9 (6): 290-293.

Imam H, Azhar M, Sofi G, Hussain A. 2013. Sweet Flag (Acorus calamus Linn.): An Incredible Medicinal Herb. Intl J Green Pharm 7 (4): 288296.

Indriyani S, Batoro J, Ekowati G. 2012. Ethnobotany of medicinal plants of Tengger Community, Bromo Tengger Semeru National Park. Natural B 1 (3): 222-228. DOI: 10.21776/ub.natural-b.2012.001.03.5.

Ismail R, Manurung R, Sihotang D, Munthe M and Tiar I, 2019, Specialization of skills and traditional treatment methods by Namalo in Batak Toba Community, Indonesia. J Ethnomed 13 (4):207-216. DOI: 10.31901/24566772.2019/13.04.593

Jaiswal A. 2019. Indigenous knowledge system and traditional medicinal practitioner. Anthropol Ethnol Open Acc J 2 (1): 000119. DOI: 10.23880/aeoaj-16000119.

Jdey A, Falleh H, Jannet SB, Hammi KM, Dauvergne X, Ksouri R, Magné C. 2017. Phytochemical investigation and antioxidant, antibacterial and antityrosinase performances of six medicinal halophytes. South Afr J Bot 112: 508-514.

Joshi R, Chelliah J. 2013. Sharing The benefit of commercialisation of traditional knowledge: What are the success factor? Nintione. 
Jumiarni W, Komalasari O. 2017. Eksplorasi dan pemanfaatan tumbuhan obat pada masyarakat suku muna di pemukiman kota Muna. Tradit Med J 22 (1): 45-56.

Kaewklom S, Petvises S, Hanpithakphong W, Aunpad R. 2018. Structural and biological features of a novel plant defensin from Brugmansia $x$ candida. PLoSONE 13 (8): e0201668. DOI: 10.1371/journal.pone.0201668

Kanedi M, Sutyarso, Busman H, Nurcahyani N, Nurkhasanah W. 2017. Root extract of purwoceng (Pimpinella pruatjan) enhances aggressiveness, but not libido, in male mice. Ann Res Rev Biol 20 (2): $1-6$.

Keshava R, Muniyappa N, Gope R. Bioactivity-guided fractionation and elucidation of anti-cancer properties of Imperata cylindrica leaf extracts. Asian Pac J Cancer Prev 21 (3): 707-714. DOI: 10.31557/APJCP.2020.21.3.707

Khashan AA. 2014. Antibacterial activity of garlic extract (Allium sativum) against Staphylococcus aureus in vitro. Global J Bio-Sci Biotechnol 3 (4): $346-348$

Kidani B, Van der Maesen, Van Andel, Asfaw Z .2014. Ethnoveterinary medicinal plants used by the Maale and Ari ethnic communities in southern Ethiopia. J Ethnopharmacol 11:53 (1) 274-82

Kobayashi J. 2009. Making the connection: Water, forest, and mineral exploitation in South and Southeast Asia. Stimson Centre, Washington DC.

Kooti W, Moradi M, Ali-Akbari S, Sharafi-Ahvazi N, Asadi-Samani M, Ashtary-Larky D. 2015. Therapeutic and pharmacological potential of Foeniculum vulgare Mill: A review. J HerbMed Pharmacol 4 (1): 1-9.

Koppula S, Kumar H. 2013. Foeniculum vulgare Mill (Umbelliferae) attenuates stress and improves memory in Wister rats. Trop J Pharm Res 12 (4): 553-558. DOI: 10.4314/tjpr.v12i4.17.

Küçükboyaci N, Güvenç A, Turan NN, Aydin A, 2012. Antioxidant activity and total phenolic content of aqueous extract from Raphanus raphanistrum L. Turk J Pharm Sci 9 (1): 93-100.

Kumar DR. 2019. United States patents, biopiracy, and cultural imperialism, the theft of India traditional knowledge. Inquiries J 11 (10): $1-11$.

Kurniawan E, Jadid N. 2015. Nilai Guna Spesies Tanaman sebagai Obat Tradisional oleh Masyarakat Tengger di Desa Ngadisari Kecamatan Sukapura, Kabupaten Probolinggo Jawa Timur. Jurnal Sains dan Seni ITS 4 (1): 1-4

Kusmana C, Hikmat A. 2015. Keanekaraman hayati flora di Indonesia Jurnal Pengelolaan Sumberdaya Alam dan Lingkungan 5 (2): 187-198. DOI: 10.19081/jpsl.5.2.187. [Indonesian]

Kuspradini H, Putri AS, Sinta, Diana R. 2020. Toxicity, antioxidant ability and inhibition of oral pathogens by monoterpene-rich essential oil of Litsea angulata Blume. Agric Nat Res 5 (2): 223-228.

Kuspradini H, Silau S, Supartini S, Rosamah E. 2019. Comparative antimicrobial studies on plant species known as 'Pasak Bumi': Eurycoma longifolia Jack., Rennelia elliptica Korth. and Trivalvaria macrophylla Miq. F1000Research 8: 301. DOI 10.12688/f1000research.16954.1

Kuspraningrum E, Luth T, Yuliati, Safa'at R 2019. Social justice for the economic rights on traditional knowledge in medicinal plants of customary law communities. J Arts Humanities 8 (12): 87-92. DOI 10.18533/journal.v8i12.1808

Kuspraningrum E, Luth T, Yuliati, Safa'at R. 2020. Protection of intellectual property rights of the Tengger adat people's knowledge. Intl J Innovation Creativity Change 12 (10): 129-138.

Kuspraningrum E. 2018. Implikasi dari tidak terlindunginya hak masyarakat hukum adat selaku pengemban pengobatan herbal tradisionoal. Laporan Hasil Penelitian pada Masyarakat Hukum Adat Tengger Jawa Timur, Malang, Indonesia. [Indonesian]

Kusumadara A. 2011. Pemeliharaan dan pelestarian pengetahuan tradisional dan ekspresi budaya tradisional Indonesia: Perlindungan hak kekayaan intelektual dan non-hak kekayaan intelektual. Jurnal Hukum Ius Quia Iustum 18 (1): 20-41. DOI: 10.20885/iustum.vol18.iss1.art2

Larsen PB, Gilbert J. 2020. Indigenous rights and ILO Convention 169: Learning from the past and challenging the future. Intl J Hum Rights 24 (2-3). DOI: 10.1080/13642987.2019.1677615

Law No. 5. 1994. Ratification of the United Nations Convention on Biological Diversity (United Nations Convention Nation Regarding Biodiversity).

Lazuardini PM, Mardiyono, Said A. 2014. Analisis peranan pemerintah terhadap perlindungan dan pengelolaan lingkungan hidup (suatu studi di lingkungan kawasan industri Gresik/KIG). Jurnal Administrasi
Publik

2:

4.

http://administrasipublik.studentjournal.ub.ac.id/index.php/jap/article/ view/499. [Indonesian]

Lee WC, Chiung-Chi P, Chi-Huang C, Shiau-Huei H, Charng-Cherng C. 2013. Extraction of antioxidant components from Bidens pilosa flowers and their uptake by human intestinal Caco-2 Cells. Molecules 18 (2): 1582-1601. DOI: 10.3390/molecules 18021582

Lekhsmi PNCJ, Viveka S, Viswanathan MB. 2015. Antimicrobial activity of Allium sativum against human pathogens. Intl J Institutes Pharm Life Sci 5 (2): 147-153.

Lenkova M, Bystrická J, Tóth T, Hrstková M. 2016. Evaluation and comparison of the content of total polyphenols and antioxidant activity of selected species of the genus Allium. J Central Eur Agric 17 (4): 1119-1133. DOI: /10.5513/JCEA01/17.4.1820

Listiyana A, Mutiah R. 2017. Pemberdayaan masyarakat Suku Tengger Ngadas Poncokusumo Kabupaten Malang dalam mengembangkan potensi tumbuhan obat dan hasil pertanian berbasis "etnofarmasi" menuju terciptanya desa mandiri. J Islamic Med 1 (1): 1-8. DOI: 10.18860/jim.v1i1.4117. [Indonesian]

Lopez MS and Paramo IS. 2016. The identification of biopiracy in patens. J. World Patent Information Vol 47, A1-A4, 1-98. DOI: 10.1016/j.wpi.2016.10.003.

Lumintang J. 2015. Pengaruh perubahan sosial terhadap kemajuan pembangunan masyarakat di desa Tara-Tara I. Acta Diurna 4: 2. [Indonesian]

Luth T, Ruba'i M, Hamidi J, Susmto B. 2017. The role of sharia economics law in sustainable development in Indonesia. J Law Policy Glob 63: 224-233.

Mahendradhata Y, Triasnantoro L, Listyadewi S, Soewondo P, Mathias T, Harimurti P, Prawira J. 2017. The Republic Indonesia Health System Review, Asia Pacific Reservatory On Health And Policies. WHO Regional Office For South East Asia 7 (1): 1-60.

Mahwasane ST, Middleton L, Boaduo N. 2013. An ethnobotanical survey of indigenous knowledge on medicinal plants used by the traditional healers of the Lwamondo area, Limpopo province, South Africa S A J Bot 88: 69-75. DOI: 10.1016/j.sajb.2013.05.004.

Malik S, Ludmilla SSdM, Carolina RS, Jose WCdM, Emmeline dSR, Jayakumar B, Rambod A, Patricia dMSF, Livio MC-J. 2019. Chemical profile and biological activities of essential oil from Artemisia vulgaris L. cultivated in Brazil. Pharmaceuticals 12 (49): 1-10. DOI: 10.3390/ph12020049.

Manisha B, Siddiqui NA, Sumeet G. 2013. Abrus precatorius (L.): An evaluation of traditional herb. Indo Am J Pharm Res 3 (4): 3295- 3315.

Marrelli M, Cristaldi B, Menichini F, Conforti F. 2015. Inhibitory effects of wild dietary plants on lipid peroxidation and on the proliferation of human cancer cells. Food Chem Toxicol 86: 16-24. DOI: 10.1016/j.fct.2015.09.011

Mathibela M, Egan BA, Plessis H, Potgieter JM, 2015. J. Ethnobiology and Ethnomedicine 11 (1):49. DOI: 10.1186/s13002-015-0025-3.

Mensah AY, Bonsu AS, Fleischer TC. 2011. Investigation of the bronchodilator activity of Abrus precatorius. Intl J Pharm Sci Rev Res 6 (2): 9-13.

Mesfin M, Asres K, Shibeshi W. 2014. Evaluation of anxiolytic activity of the essential oil of the aerial part of Foeniculum vulgare Miller in mice. BMC Compl Altern Med 14 (1): 310. DOI: 10.1186/1472-6882-14310.

Metwally DM, Al-Olayan EM, Alanazi M. 2018. Antischistosomal and anti-inflammatory activity of garlic and allicin compared with that of praziquantel in vivo. BMC Compl Altern Med 18 (1): 135. DOI: 10.1186/s12906-018-2191-z.

Meyers GD, Owoeye OA. 2013. Intellectual property law and protection of indigenous Australian knowledge in natural resources. J Law Info Sci 22 (2): $57-74$

Mgbeoji I. 2007. Global Piracy, Patents, Plants and Indigenous Knowledge. UBC Press, Toronto.

Mirabolghasemi G, Alizadeh F. 2014. The Effect of hydroalcoholic extract of Fennel (Foeniculum vulgare) seed on serum levels of sexual hormones in female Wistar rats with Polycystic Ovarian Syndrome (PCOS). Arak Med Univ J 17 (86): 70-78.

Moffatt A. 2012. Indonesian Cultural Profile. Diversicare, Australia.

Moh-ud-din R, Farooq S, Majeed A, Khan NA, and Bhat ZA. 2019. Legal framework on protection of traditional knowledge: A review. Intl J Adv Res Sci Eng 8 (1): 100-109.

Mohammed GJ, Hameed IH. 2018. Pharmacological activities: Hepatoprotective, cardioprotective, anti-cancer and anti-microbial activity of (Raphanus raphanistrum Subsp. sativus): A review. Indian 
J Public Health Res Develop 9 (3): 212-217. DOI: 10.5958/0976 5506.2018.00211.5

Mokrani A, Stephanie K, Stephanie C, Gregory DC, Hamza T, Elodie R, Jean-Michel M, Khodir M, Marc M, Arnaud M, Tristan R. 2015 Phenolic contents and bioactive potential of peach fruit extracts. Food Chem 202: 212-220. DOI: 10.1016/j.foodchem.2015.12.026

Murphy T. 2019. Natural Law Natural Justice: A Thomistic Perspective, Research Handbook on Natural Law Theory (Crowe and Lee (eds.). Edward Elgar Publishing Limited, Cheltenham UK.

Mutalib MA, Asmah R, Faisal A, Fauziah O, Rajesh R. 2017. Nutritional compositions and antiproliferative activities of different solvent fractions from ethanol extract of Cyphomandra betacea (Tamarillo) fruit. Malays J Med Sci 24 (5): 19-32. DOI: 10.1016/j.foodchem.2015.12.026

Mutalib MA, Faisal A, Fauziah O, Rajesh R, Asmah R. 2016. Phenolics profile and anti-proliferative activity of Cyphomandra Betacea fruit in breast and liver cancer cells. SpringerPlus 5: 2105. DOI: 10.1186/s40064-016-3777-x.

Nahdi MS, Pramudya A, Kurniawan. 2019. Ehnobotanical study in Gunung Kidul, Yogyakarta, Indonesia. Nusantara Biosci 1 (2): 133-141. DOI 10.13057/nusbiosci/n110204

Najafian Y, Shokouh SH, Masoumeh KF, Zohre F. 2018. Plantago major in traditional Persian medicine and modern phytotherapy: A narrative review. Electronic Physician 10 (2): 6390-6399. DOI: 10.19082/6390.

Nakagawa T, Ahmed EA, Koichiro O, Kuniyoshi S. 2018. Biological activities of extracts from different parts of two cultivars of Prunu persica Ákatsuki and Fastigiata. Nat Prod Commun 13 (10): 1293 1296.

Nayeem AA, Khatun A, Rahman Md S, Mahmudur Rahman M. 2011. Evaluation of phytochemical and pharmacological properties of Mikania cordata (Asteraceae) leaves. J Pharmacogn Phytother 3 (8): 118-123.

Nonaka I, Takeuchi H. 1995. The knowledge-creating company: how japanese companies create the dynamics of innovation. Oxford University Press, New York.

Nurcahyanti ADR, Nasser IJ, Sporer F, Graf J, Bermawie N, Reichling J, Wink M. 2016. Chemical composition of the essential oil from aerial parts of Javanian Pimpinella pruatjan Molk. and its molecular phylogeny. Diversity 8 (15): 1-9. DOI: $10.3390 / \mathrm{d} 8030015$.

Nurdjaya IN, Safaat R. 2016. Access to Ecological Justice for The Marginalized People of Indonesia: Is it Genuine or Pseudo Recognition and Respect?. Indonesia Law Rev 2016 1: 97-110.

Obioha UP. 2011. The Nature of Justice. J Soc Sci 29 (2): 183-192. DOI: 10.1080/09718923.2011.11892969.

Packer J, Turpin G, Ens E, Venkataya B, Mbabaram Community, Rangers Y, Hunter J. 2019. Building partnerships for linking biomedical science with traditional knowledge of customary medicine: Case of two Australian indigenous communities. J Ethnobiol Ethnomed 15 (1): 211. DOI: $10.1186 / 513002-019-0348-6$

Pager SA. 2016. Traditional knowledge right and wrong. Virginian J Law Technol 20 (1): 82-198.

Palar MRA, Rasiah R. 2019. Universalization of Indonesian cultural and scientific regulations. Afr J Sci Technol Innov Dev 11 (7): 873-882. DOI: $10.1080 / 20421338.2019 .1588510$.

Pandey BP, Thapa R, Upreti A. 2017. Chemical composition, antioxidant and antibacterial activities of essential oil and methanol extract of Artemisia vulgaris and Gaultheria fragrantissima collected from Nepal. Asian Pac J Trop Med 10 (10): 952-959. DOI: 10.1016/j.apjtm.2017.09.005

Pavan V, Sancho RAS, Pastore GM. 2014. The effect of in vitro digestion on the antioxidant activity of fruit extracts (Carica papaya, Artocarpus heterophyllous and Annona marcgravii). LWT - Food Sci Technol 59 (2): 1247-1251. DOI: 10.1016/j.lwt.2014.05.040.

Persoon GA, Minter T. 2011. Code and Conduct for Working with Indigenous and Local Communities. Tropenbos International, Wageningen, The Netherlands.

Pourabbas S, Kesmati M, Rasekh A. 2011. Study of the anxiolytic effects of fennel and possible roles of both gabaergic system and estrogen receptors in these effects in adult female rat. Physiol Pharmacol 15 (1): $134-143$

Priambodo BB. 2018. Positioning adat law in Indonesia's legal system: Historical discourse and current development on customary law. $\begin{array}{lllll}\text { Udayana J Law Culture. } 2 & \text { (2): 140-164. DOI: }\end{array}$ 10.24843/UJLC.2018.v02.i02.p02.

Pritchard D, Neta R. 2009. Arguing about Knowledge. Routledge, USA.
Purwestri YA, Nuráini K, Sartika GP, Wildani W, Langkah S. 2016. Metabolic profiling of endophytic bacteria from purwoceng (Pimpinella pruatjan Molkend) root and antibacterial activity against Staphylococcus aureus and Pseudomonas aeruginosa. AIP Conf Proc 1744: 020063. DOI: $10.1063 / 1.4953537$.

Qiang F. 2011. Effects of Foeniculum vulgare Mill on lipid peroxidation in rats with liver hepatic fibrosis. [Dissertation]. Xinjiang Medical University, Xinjiang.

Rahayu SE, Sulisetijono, Umie L. 2019. Phytochemical screening, antioxidant activity, and total phenol profile of Carica pubescens leaves from Cangar, Batu-East Java, Indonesia. IOP Conf Ser Earth Environ Sci. DOI: 10.1088/1755-1315/276/1/012022.

Rahimi R, Ardekani MRS. 2013. Medicinal properties of Foeniculum vulgare Mill. in traditional Iranian medicine and modern phytotherapy. Chin J Integr Med 19: 73-79. DOI: 10.1007/s11655-013-1327-0.

Rahman MM, Fazlic V, Saad NW. 2012. Antioxidant properties of raw garlic (Allium sativum) extract. Intl Food Res J 19 (2): 589-591.

Rather M, Dar BA, Sofi SN, Bhat BA, Qurishi MA. 2012. Foeniculum vulgare: A comprehensive review of its traditional use, phytochemistry, pharmacology, and safety. Arabian J Chem 9 (2): S1574-S1583. DOI: 10.1016/j.arabjc.2012.04.011.

Rattanapan J, Sichaem J, Tip-pyang S. 2012. Chemical constituents and antioxidant activity from the stems of Alyxia reinwardtii. Rec Nat Prod 6 (3): 288-291.

Reny E, Luth T, Sihabudin, Hamidah S. 2020. The development politics of law in Indonesia sharia economic environment. International Conference on Environment and Technology. DOI: 10.1088/17551315/469/1/01219.

Rinaldi Y. 2015. Concept of justice in the management of natural resources, Jurnal Dinamika Hukum 15 (1): 26-33.

Robinson DF. 2010. Confronting Biopiracy: Challenges, Cases and International Debates. Earthscan, London.

Robinson, Raven. 2017. Identifying and preventing biopiracy in Australia, patent landscape and legal geographies for plants with indigenous Australian uses. Australian Geographer 48 (3): 311-331 DOI: 10.1080/00049182.20116.1229240.

Roderick L, Merculieff I. 2013. Stop Talking: Indigenous Ways to Teaching and Learning and Difficult Dialogues in Higher Education. University of Alaska Anchorage, Anchorage, AK.

Rohman F, Jurna Y, Soelisetjiono, Utomo DH, Purwanto, Lestari SR, Arifah SN, Putra WE. 2019. Plant diversity as medicinal plant by Tengger tribe, Bromo Tengger Semeru National Park, East Java Indonesia. EurAsian J Biosci 13 (2): 2293-2298.

Ruslin, Asmawi MZ, Rianse U, Sahidin I, Dhianawaty D, Soemardji DA, Amalia L. 2013. Anti-hypersensitive activity of alang-alang (Imperata cylindrica (L.) Beauv. root methanolic extract on male Wistar rat. Intl J Res Pharm Sci 4 (4): 537-542.

Sadurski W. 2017. Justice. Routledge, London.

Safa'at R. 2011. Peranan hukum progresif dalam transformasi sistem ekonomi yang berkeadilan sosial. Jurnal Hukum Progresif 4 (1): 60-77. DOI: 10.14710/hp.4.1.60-77. [Indonesian]

Safa'at R. 2013. Ambivalensi pendekatan yuridis normatif dan yuridis sosiologis menelaah sistem kearifan lokal masyarakat adat dalam pengelolaan sumber daya alam. Lex Jurnalica 10 (1): 46-62. [Indonesian]

Safa'at R. 2013. Rekonstruksi Politik Hukum Pangan. UB Press, Malang. [Indonesian]

Saleng A. 2013. Kapita Selekta Hukum Sumber Daya Alam. Membumi Publishing, Makasar. [Indonesian]

Satria D. 2013. Complimentary and alternative medicine centre (CAM): A fact or promise. Idea Nursing J IV (3): 82-90.

Satyal P, Prajwal P, Ambika P, Noura SD, Debra MM, Bernhard V, William NS. 2013. Chemical compositions, phytotoxicity, and biological activities of Acorus calamus essential oils from Nepal. Nat Prod Commun 8 (8): 1179-1181.

Senanayake SGJN. 2006. Indigenous knowledge is key to sustainable development. J Agric Sci 2 (1): 87-94. DOI: 10.4038/jas.v2i1.8117a.

Shahat AA, Ibrahim AY, Hendawy SF, Omer EA, Hammouda FM, AbdelRahman FH, Saleh MA. 2011. Chemical composition, antimicrobial and antioxidant activities of essential oils from organically cultivated fennel cultivars. Molecules 16 (2): 1366-1377.

Shang A, Cao SY, Xu XY, Gan RY, Tang GY, Corke H, Mavumengwana V, Li HB. 2019. Bioactive compounds and biological functions of garlic (Allium sativum L.). Foods 8 (7): $246 . \quad$ DOI: $10.3390 /$ foods 8070246 . 
Sharma B, Maurya SS, and Bramacharimayum J. 2018. India's fight against agricultural and medicinal plants' biopiracy: Its implications on food security, traditional rights and knowledge degradation. Intl J Agric Environ Biotechnol 11 (6): 881-887. DOI: 10.30954/09741712.12.2018.9

Shiva V. 2013. The Neem Tree. A Cas History of Biopiracy. Available at www.twnside.org.sg./tilte/pir-ch.htm Accessed 1 February 2020.

Shourie A, Kalra K. 2013. Analysis of phytochemical constituents and pharmacological properties of Abrus precatorius L. Intl J Pharm Bio Sci 4 (1): 91-101.

Singh H, Husain T, Agnihotri P, Khatoon S. 2014. An Ethnobotanical study of medicinal plants used in sacred groves of Kumaon Himalaya, Uttarakhand, India, J Ethnopharmacol 154 (1) DOI: 10.1016/j.jep.2014.03.026.

Singh G, Passsari AK, Singh P, Leo VV, Subbarayan S, Kumar B, Singh BP, Lalhlenmawia H, Kumar NS. 2017. Pharmacological potential of Bidens pilosa $\mathrm{L}$. and determination of bioactive compounds using UHPLC-QqQLIT-MS/MS and GC/MS. BMC ComplAltern Med 17: 492. DOI: 101186/s12966-017-2000-0

Subramanian R, Shaver L. 2011. Access to Knowledge in India: New Research on Intellectual Property, Innovation and Development. Bloomsbury Academic, UK.

Syah H. 2013. Urbanization and modernization (A studies about the change of cultural value system to urban community Pangkalan Kerinci Pelalawan. Toleransi 5 (1): 1-12.

Tang K. 2016. Our way of life: Importance of indigenous culture and tradition to physical activity practice. Intl J Indigenous Health 11 (1) 211-227. DOI: $10.18357 /$ ijih111201616018

Taur DJ, Patil RY. 2011. Mast cell stabilizing and antiallergic activity of Abrus precatorius in the management of asthma. Asian Pac J Trop Med 4 (1): 46-49. DOI: 10.1016/S1995-7645 (11)60030-8.

Ter Haar, 1979, Asas-Asas dan Susunan Hukum Adat, translated by K. Ng. Soebakti Poesponoto, Pradnya Paramita, Jakarta. [Indonesian]

Thomas D, Karuki M, Magero C, Schenk A. 2016. Local People and Government Working Together to Manage Natural Resources: Lessons from the Lake Victoria Basin. BirdLife Africa, Nairobi.

Thomson M, Ali M. 2003. Garlic (Allium sativum): A review of its potential use as an anti-cancer agent. Curr Cancer Drug Targets 3 (1): 67-81. DOI: $10.2174 / 1568009033333736$.
UNESCO. 2011. Investing in Cultural Diversity and Intercultural Diversity Dialog: UNESCO World Report; Executive Summary, Jakarta. UNESCO Office, Jakarta.

Ushie V. 2013. The management and use of natural resources and their potential for economic and social development in the Mediterranean. IAI Working Paper 3 (29): 1-34.

Vandana J, Gupta AK, Mukerjee A. 2017. Pharmacological activities of miraculous plant Plantago Major L.: A review. Intl J Chem Physic Sci 6 (3): 26-37.

Verma S and Singh SP. 2008. Current and future status of herbal medicine. Vet World 2 (2):347. DOI: 10.5455/vetworld.2008.347-350

Vega J. 2018. Legal Philosophi and practical Philosophi. Revus 34. DOI: 10.4000//revus.3859.

Wibisono HK, Trianita LN, Widagdo S. 2013. Dimension of Pancasila Ethics. In Bureaucracy: Discourse of Governance (Philosophy, Ethics, and Local Wisdom for The Moral Construction of Nationalities), Geneva.

WIPO IP Portal. WIPO PatentScope. https: //patentscope.wipo.int/beta/en/search.jsf

Wiradirja IR, Munzil F. 2018. Pengetahuan Tradisional dan Hak Kekayaan Intelektual, Perlindungan Pengetahuan Tradisional berdasarkan Azas Keadilan melalui Sui Generis Intellectual Property System. PT Refika Aditama, Bandung. [Indonesian]

Yang K, Wang CF, You CX, Geng ZF, Sun RQ, Guo SS, Du SS, Liu ZL, Deng ZW. 2014. Bioactivity of essential oil of Litsea cubeba from China and its main compounds against two stored product insects. J Asia-Pac Entomol 17 (3): 459-466. DOI: 10.1016/j.aspen.2014.03.011

Zainol ZA, Amin L, Akroviri, Ramli R. 2011. Biopiracy and states, sovereignty over their biological resources. Afr J Biotechnol 10 (58): 12395-12408

Zubair M, Widen C, Renvert S, Rumpunen K. 2019. Water and ethanol extracts of Plantago major leaves show anti-inflammatory activity on oral epithelial cells. J Trad Compl Med 9 (3): 169-171. DOI: 10.1016/j.jtcme.2017.09.002

Zulkarnain, Raharjo KM. 2019. Inheritance of the Customary Norm of Informal Education in The Tengger Community of Ngadas Village, East Java Indonesia. IJICC Special Edition ICET Malang 5 (5): 1-14. 